\title{
Investment, Employment and Financial Performance Evidence from Cooperative Enterprises of Fars province
}

\author{
Javad Moradi, $\mathrm{PhD}^{\mathrm{a}}$, Marzieh Nematollahi ${ }^{\mathrm{b}}$ \\ ${ }^{a}$ Accounting Department, Shiraz University, Shiraz, Iran \\ ${ }^{b}$ First Affiliation, Address, City and Postcode, Country
}

\begin{abstract}
Investing huge resources in different parts of economic and industrial sectors to increase and promote public welfare and also, provide opportunities for country's reserves' growth. Therefore, identifying accurate opportunities for investment is critical, since it helps investors to know the maximum benefits to the economy coupled with the greatest influences in removing the country`s economic problems and difficulties, especially in employment. This article investigates the relationship between investments, employment and the financial performance of the active cooperative enterprises of Fars province in Iran. Based on the considered conditions, 120 firms were selected from the population on the basis of the classified random sampling method during the period 2006-2011. The findings indicate that there is a positive and meaningful relationship between investment and employment in cooperative enterprises. Also, the results show that there is a significant difference among the financial performance of cooperative enterprises in different sectors on the basis of invested capital. Specifically, the increasing investments in agricultural and industrial sectors have led to higher Return On Assets (ROA) ratio.
\end{abstract}

Keywords: Investment; Employment; Financial Performance; ROA

\section{(C) 2013 Published by SSBFNET}

\section{Introduction}

Investing huge resources in different parts of economic and industrial sectors to increase and promote public welfare and also, provide opportunities for country`s reserves' growth. Therefore, identifying accurate opportunities for investment is critical, since it helps investors to know the maximum benefits to the economy coupled with the greatest influences in removing the country`s economic problems and difficulties, especially in employment. In economic literature, especially in developing countries who suffer doubled-digit unemployment rates, employment is a key factor considering by regulators and governments. This is more tangible for Iran's economy, because during the last two decades it has experienced relatively high population growth, inasmuch as it is still affecting the employment rates. Thus, considering the level of employment to be only affected by the variables of labor demand makes possible the issue of employment analysis. Theoretically, it is expected that the variable of employment rates is a direct function of the gross domestic product (GDP) and investments in public and private sectors (Tajalli et al., 2010). Hence, this paper is to examine the performance of cooperative companies and also ways and strategies to improve it

\footnotetext{
${ }^{a}$ Corresponding author. Tel: +989171882644
} 
and promote its efficiency. Not only assessments help managers to apply correct strategies and financial structures selection, but also it shows how they influence in economic unit value. Moreover, performance evaluation can be effective for investment decisions and it makes answering to these kinds of questions easy: has establishing a business been done along with conventional values? Do different parts of an enterprise create value or possess efficiency? Which parts or units should be sold or restructured? Evaluation helps managers to deeply understand their improvement of value creation and find a way to measure and evaluate their strategic and current financial structure failures. In recent years, there is an increasing growth of cooperative enterprises and government's focuses on importance of this kind of firms in Iran. But, according to the investments required, the main question is that whether a growth in the cooperative sector will meet the needs of the society, or what have been the results of this in order to resolve the social problems such as unemployment, and what is the role of this section, in growing productivity and performance? Considering the role and position of the cooperative sector in Iran and the increasing attention of the government to these business entities to meet the goals of the second paragraph of Article 43 and the enforcement of the government to provide necessary facilities for the establishment and development of the Cooperative companies, investigating the performance of this sector is critical from the efficiency point of view. Moreover, each year, several sources of funding or bank resources guaranteed by the government with interest-free loans are granted to the cooperative sector; and the Article 44 of Iranian Constitution and the Supreme Leader stress on employment, make clearer the role of the cooperatives in this regard. Cooperation is as an appropriate leverage for the economic developments that may be effective for improving the level of working conditions, life, production and income along with the government policies. In fact, the members of cooperative companies are the main capital and real driving force of the cooperative sector. They try to meet their needs, objectives and cooperation-employment, and promoting productivity are the most important of them achieved by small savings, accumulating capital, and physical and intellectual contributions as well. Some experts consider cooperation as a great tool for the economic and social developments and also, the main factors for improving employment and entrepreneurship (Mollahosseini \& Mohammadi, 2010). An important principle of management is expressed as follows:

\section{"If you can 't measure something, you will not be able to handle it."}

Today, there are many surprising developments in the area of management that has made inevitable the existence of the evaluation system. Therefore, the absence of evaluation in various aspects including the use of employee's resources and facilities and the degree of achieving goals and projected strategies, is regarded as an organizational disease symptom. In fact, measuring financial performance is considered as a priority in all economic decisions about companies (Haj-Sayyed-Javadi \& Samadi, 2009). It should be noted that the importance of the cooperative sector cannot be denied in the area of employment in Iran. Apparently, a cooperative company plays an important role in employment in addition to the significant increase in the quality and quantity of products and services in the society. Therefore, developing the cooperative sector is considered highly critical (Ourangi et al., 2010).

Evaluating the elements of economic systems at macro-level shows that the cooperative sector, as one of the three sectors of national economy in Iran, has paved the way for the people's effective contribution in their economicalsocial activities and has played an important role in the development of employment opportunities in the society as well (Lahsaiee-zadeh, 1384).

Capital investment is an important factor in all businesses, and entrepreneurs and investors are concerned about the efficiency of their invested capital. Manufacturing and service providers need to supply enough capital from different sources to launch or maintain their business. Enterprises' ability to determine the potential financial resources required for the capital investment and planning for appropriate financial programs are major factors in development and growth of a business (Hosseini \& Soori, 2009). Therefore, planning an appropriate model to evaluate the financial performance of the cooperative companies that invest in cooperative sectors and their role in employment as primary object of developing them, and the performance evaluation of capital investments in various parts of the cooperative sector, is of utmost importance.

This paper attempts to find some evidences into the performance of the cooperative companies in Fars province with respect to their role in society. In fact, this article is trying to discover all strengths and weaknesses of the cooperative sector from the viewpoint of investment, employment, and the financial performance of the active cooperative companies of Fars province in different industries and sectors. The underlying objective is to make some practical guidelines and tips to improve investment and employment problems and difficulties in this sector. It also evaluates the efficiency of the resources spent on such sectors to help utilizing the resources. Despite the importance of this area 
of research, no study has been conducted on this sector within the country yet. In the next section we will review the literature.

\section{Literature review}

Generally, there are some traditional measures used to assess the financial performance of all businesses and it is critical for them to know the outcomes of the performance. Despite the significance of this area of research, no study has been done on the cooperative sector within the country. Thus, at the next steps, some studies which are similar to this area are reviewed.

Bazdar Ardebili and Rezaee Arjroudi (2008) examined the relationship between investment and employment in transportation sector. They concluded that investing in this sector related to employment is very important to analyze macroeconomic and policymaking issues. Their research findings show that the number of employees increases by growing capital stocks in this sector. Karimi et al. (2010) evaluated the effect of financial leverage and companies' growth opportunities on investment decisions made about the companies accepted in Tehran Stock Exchange (TSE). They showed that financial leverage influences such decisions, and there is a negative and meaningful relationship between financial leverage and decisions made about investment.

Noorvash and Yazdani (2010) studied the influence of financial leverage in the companies listed in TSE. They indicated that there are many theories for analyzing and explaining the relationship between leverage and investment. Moreover, many empirical papers had examined these relationships and determinants. Their research results show that there is a negative and meaningful relationship between financial leverage and investment. Shourvarzi and Azadvar (2010) analyzed the relationship between investment opportunities and the performance of companies, concluding that the investors were trying to maximize their wealth.

Development opportunities play a role as a reward or driving force to motivate them. Furthermore, they declared that timely and reasonable use of business investment opportunities has a significant role in improving companies' performances. When they performed the statistical test, they also concluded that there is a meaningful and positive relationship between investment opportunities and companies` performances. Johnson and Swennen (2000) in a study on 478 companies during the period 1982-1998 considered 10 indicators as benchmarks of the successful companies, noting that profitability and liquidity are remarkably regarded as important for evaluating the financial performance of companies among these important indicators. Profitability is considered to be one of the most important of them for evaluating the financial performance of companies, which is calculated by using criteria such as return on asset (ROA) or gross operating profit (Fathi and Tavakkoli, 2009).

Garcia et al. (2007) assessed the small and medium Spanish companies during the period 1996-2002. They argued that managers will be able to improve value creation and profits if they reduce the time of maintenance, inventory, receiving their demands, and finally cash flows (Mollahosseini and Mohammadi, 2010). Kaur (2006) measured the performance of some small and large cooperative companies in Malaysia, applying criteria such as $\mathrm{EPM}^{\mathrm{b}}$, ROE and ROA. His findings show that there are major differences among the performances of these companies (small and large) based on the financial indicators, and the level of satisfaction in small cooperative companies are higher than the larger ones (Mollahosseini and Mohammadi, 2010). Sung (2009) examined empirically the relationship between the financial leverage and investment of Chinese industrial companies. His paper shows that there is a positive and meaningful relationship between financial leverage and investment.

\section{Methodology and hypotheses development}

In this paper, the regression model is used to test the hypotheses. First, regression models are used to examine separately the relationship between dependent and independent variables. At the next step, the relationship between all dependent and independent variables are surveyed by multiple regression model. Considering there is no any integrated system of information of the active cooperative companies of Fars province in order to examine the relationship between their investment, employment and performance, it is prepared by means of the financial statements of cooperative companies and administration and various available books and articles in addition.

\footnotetext{
${ }^{b}$ Earnings Per Member
} 
The SPSS software is also applied to analyze data, and the research questions and hypotheses are tested and examined using inferential statistical methods (Pearson correlation, multiple regression and ANOVA). When scarce resources are used, it should be noted that the maximum profits and returns should be obtained. Hence, it is expected that investments are generally focused on the opportunities which lead to maximization of productivity and have the most possible influence in mitigating economic problems and difficulties of the society, specially, unemployment. Theoretically, it is expected that the variable of employment rates is a direct function of GDP and investments in public and private sectors (Tajalli et al., 2010). Therefore, the relationship between investments in cooperative sector and employment are examined in order to evaluate the resulted outcomes and achievements of this sector, and to benchmark and compare investment opportunities available to investors. The first hypothesis is as follows:

Hypothesis 1: there is a positive and significant relationship between employment and investments in active cooperative companies of Fars province.

Regression model 1, is used to examine the first research hypothesis:

$$
(1)+\beta_{4} \text { ROA EMP }=\alpha_{0}+\beta_{1} \text { INV }+\beta_{2} \text { SIZE }+\beta_{3} \text { FLEV }
$$

Calculating the variables is described in Table 1:

Table 1: Research Variables

\begin{tabular}{|c|c|c|}
\hline Variable & Type of Variable & calculation \\
\hline Employment (EMP) & Dependent & The number of employee`s logarithm \\
\hline \multirow{2}{*}{ Investment (INV) } & \multirow{2}{*}{ Independent } & (Interest bearer`s liabilities +Equity) \\
\hline & & Total assets \\
\hline Company size (Size) & Control & Total earnings logarithm \\
\hline \multirow{2}{*}{$\begin{array}{l}\text { Financial } \\
(\text { FLEV) }\end{array}$} & \multirow{2}{*}{ Control } & Total long-term liabilities \\
\hline & & Total assets \\
\hline \multirow{2}{*}{ Return on assets (ROA) } & \multirow{2}{*}{ Control } & (Net profit + Interest cost) \\
\hline & & Mean of total assets \\
\hline
\end{tabular}

Certainly, depending on environmental features of each area and the nature of economic activities, investment returns will be different in various sectors. Obviously, when decisions are made about where and how to invest the resources, it is very important to know about where they should be invested to maximize productivity with respect to the existing opportunities. Thus, in the second hypothesis of this research, the financial performance of various parts of the cooperative sector is evaluated (but in Fars province, under special conditions) according to the amount of each part's investments. Thereby, it is provided to compare investment opportunities in cooperative sector with the other sectors of this province. Then, it is possible to direct resources to the opportunities which are proper to gain higher returns. The second hypothesis of this research is stated as following:

Hypothesis 2: there is a significant difference among cooperative companies 'financial performance in different sectors with regard to invested capital.

Generally, there are some traditional criteria to assess the financial performance of an economic entity. In this paper, ROA criteria - an indicator of how to use resources by companies and also assess the efficiency of them - has been applied. The second hypothesis performed by multiple-comparison tests after the conduction of AVOVA test, determine whether the mean differences between groups are significant or not. However, LSD multiple comparisons tests have been used in this article. 


\section{Sample selection}

The population of this paper includes all active cooperative companies of Fars province. They are all classified into 11 sub-sector companies (agriculture, services, industrial, transportation, credit, handmade carpet, real estate, mineral, civil, consumer needs, the needs of the service trust and multipurpose), the numbers of which amount to 4512 . However, because of some restrictions (as follows), only 1300 active cooperative companies of Fars province are examined and the sampling performed in accordance with the classified random sampling method during the period 1384 to 2010 (2006-2011), includes 120 companies from the population with regard to the following restrictions:

The selected companies must not be operatively inactive during the period of research.

They should have a suitable financial and accounting system and also, they must have provided their financial statements.

\section{Data analysis}

\section{1. Descriptive statistics}

Descriptive statistics of variables are presented in Table 2.

Table 2-Descriptive statistics of the sample

\begin{tabular}{llllll}
\hline Description & ROA & EMP & INV & Size & FLEV \\
\hline Number & 720 & 720 & 720 & 720 & 720 \\
Mean & 0.4562 & 1.2125 & 0.8188 & 9.0251 & 0.1989 \\
Median & 0.1764 & 1.1761 & 0.9383 & 8.8974 & 0.0656 \\
$\begin{array}{l}\text { Standard } \\
\text { deviation }\end{array}$ & 0.5464 & 0.3204 & 0.3042 & 1.2946 & 0.2913 \\
\hline
\end{tabular}

5. 2. Dependent variables normality test

Kolmogorove-smirnov testing results depended to the standard distribution of dependent variables (employment) of this study is presented in Table 3. According to the table, the significant level is higher than 5\% (sig $>0 / 05$ ). Thus, dependent variable normality is approved.

Table 3-The model's dependent variable test

\begin{tabular}{llll}
\hline Variable & Number & Kolmogorove-smirnov Z & $\begin{array}{l}\text { Asymp. Sig. (2- } \\
\text { tailed) }\end{array}$ \\
\hline EMP & 720 & 1.311 & $0 / 064$ \\
\hline
\end{tabular}




\section{3. Pearson correlation}

Table 4 shows information about variables correlations (Pearson correlation). As is clear, the highest correlation with employment is related to the financial performance variable and the lowest meaningful correlation is associated with the size variable. Moreover, there is not any meaningful relationship between leverage and employment.

Table 4 - Pearson Correlation

\begin{tabular}{lllllll}
\hline Description & & Size & ROA & INV & FLEV & EMP \\
\hline \multirow{3}{*}{ EMP } & correlation & $0.365^{* *}$ & $0.451^{* *}$ & $0.405^{* *}$ & -0.007 & 1 \\
& Sig. level & 0.000 & 0.000 & 0.000 & 0.850 & 0 \\
& Number & 720 & 720 & 720 & 720 & 720 \\
& correlation & $0.102^{* *}$ & -0.003 & $-0.645^{* *}$ & 1 & -0.007 \\
FLEV & Sig. level & 0.006 & 0.928 & 0.000 & 0 & 0.850 \\
& Number & 720 & 720 & 720 & 720 & 720 \\
& correlation & $0.243^{* *}$ & $0.309^{* *}$ & 1 & $-0.645^{* *}$ & $0.405^{* *}$ \\
INV & Sig. level & 0.000 & 0.000 & 0 & 0.000 & 0.000 \\
& Number & 720 & 720 & 720 & 720 & 720 \\
ROA & correlation & $0.289^{* *}$ & 1 & $0.309^{* *}$ & -0.003 & $0.451^{* *}$ \\
& Sig. level & 0.000 & 0 & 0.000 & 0.928 & 0.000 \\
& Number & 720 & 720 & 720 & 720 & 720 \\
& correlation & 1 & $0.289^{* *}$ & $0.243^{* *}$ & $0.102^{* *}$ & $0.365^{* *}$ \\
& Sig. level & 0 & 0.000 & 0.000 & 0.006 & 0.000 \\
& Number & 720 & 720 & 720 & 720 & 720 \\
\hline
\end{tabular}

** Correlation is significant at the level $0 / 01$

* Correlation is significant at the level 0/05

\section{4. Testing the first hypothesis}

As it mentioned before, the first hypothesis of this research is presented as follows:

Hypothesis 1: there is a positive and significant relationship between employment and investments in active cooperative companies of Fars province.

Results provided from testing model, have been summarized in Tables 5 and 6 . As is observed, the regression model used is meaningful and independent variables, can explain about 32 percent of changing in dependent variable (employment). According to the positive independent variable coefficient, there is a positive and meaningful relationship between investment and employment in cooperative enterprises. 
Table 5 - Testing results for the first hypothesis (ANOVA)

\begin{tabular}{llllll}
\hline Model & Sig. & R & R Square & adjusted $\mathbf{R}^{\mathbf{2}}$ & Durbin-Watson \\
\hline 1 & 0.000 & 0.451 & 0.204 & 0.322 & 1.862 \\
\hline
\end{tabular}

Table 6 -independent variables` coefficient Significance

\begin{tabular}{lllllll}
\hline \multirow{2}{*}{ Description } & & \multicolumn{2}{l}{ Unstandardized coefficients } & standardized coefficients & t & Sig. \\
\cline { 2 - 7 } & & $\mathbf{B}$ & Std. Error & Beta & 6.394 & 0.000 \\
\hline \multirow{3}{*}{ Model } & constant & 0.470 & 0.073 & & 9.317 & 0.000 \\
\cline { 2 - 7 } & ROA & 0.131 & 0.014 & 0.310 & 7.847 & 0.000 \\
\cline { 2 - 7 } & INV & 0.259 & 0.033 & 0.253 & 6.516 & 0.000 \\
\hline
\end{tabular}

According to table 6, it may be concluded that there is a significant relationship between independent variables as investment, financial performance and size with employment. Therefore, the final model is determined as follow:

$E M P=0.470+0.131 R O A+0.259 I N V+0.053 S I Z E$

The first hypothesis, thus, is confirmed on the basis of the relationship between employment and investment in cooperative companies. Therefore, It can be generally acknowledged that the employment rates (in Fars province cooperative sector) have risen with an increase in investment in cooperative sector. The size and return on assets, positively and significantly, are related to employment rates. But there is not any meaningful relationship between the financial leverage and employment.

\section{5. Testing the second hypothesis of the research}

As it mentioned before, the second hypothesis of this research is presented as follows:

Hypothesis 1: there is a significant difference among cooperative companies 'financial performance in different sectors with regard to investments performed.

In this section, first, the sample cooperative companies are divided into three groups (low, middle and high) based on the invested capital. Table 7 shows the descriptive Statistics of each sector.

Table 7- descriptive Statistics of variables, according to the quartiles of investments

\begin{tabular}{llllllll}
\hline \multirow{2}{*}{$\begin{array}{l}\text { Capital } \\
\text { investment }\end{array}$} & \multirow{2}{*}{ Number } & Mean & St.d. & \multicolumn{2}{c}{ Confidence interval (95\%) } & \multirow{2}{*}{ Minimum } & \multirow{2}{*}{ Maximum } \\
\cline { 5 - 6 } & & & & Lower bound & Upper bound & & \\
\hline Low & 240 & 0.3957 & 0.52558 & 0.3289 & 0.4645 & -0.87 & 2.62 \\
Middle & 240 & 0.4068 & 0.49579 & 0.3438 & 0.4699 & -1.08 & 2.87 \\
high & 240 & 0.5661 & 0.59828 & 0.4900 & 0.4622 & -0.13 & 2.97 \\
Total & 720 & 0.4562 & 0.54642 & 0.4162 & 0.4962 & -1.08 & 2.97 \\
\hline
\end{tabular}


Table 8- ANOVA (Comparing the financial performance of investment quartiles)

\begin{tabular}{lllllll}
\hline Description & & Sum of squares & df & Mean squares & F & Sig. \\
\hline \multirow{2}{*}{ Model } & Between groups & 4.364 & 2 & 2.182 & 7.438 & 0.001 \\
& Within groups & 210.314 & 717 & 0.293 & \\
& Total & 214.678 & 719 & & \\
\hline
\end{tabular}

The results show that, at least, there is a meaningful difference between the two groups' financial performance. Therefore, in order to determine the significance of the performance difference precisely, multiple comparison tests are presented in Table 9.

Table9- Multiple comparisons between various investment quartiles

\begin{tabular}{|c|c|c|c|c|c|c|}
\hline \multirow[b]{2}{*}{ Group (I) } & \multirow[b]{2}{*}{ Group (J) } & \multirow{2}{*}{$\begin{array}{l}\text { Mean difference } \\
\text { (i-j) }\end{array}$} & \multirow[b]{2}{*}{ Std. error } & \multirow[b]{2}{*}{ Sig. } & \multicolumn{2}{|c|}{ 95\% Confidence interval } \\
\hline & & & & & $\begin{array}{l}\text { Lower } \\
\text { bound }\end{array}$ & $\begin{array}{l}\text { Upper } \\
\text { bound }\end{array}$ \\
\hline \multirow{3}{*}{$\begin{array}{l}\text { Low } \\
\text { investment }\end{array}$} & Low-Inv & & & & & \\
\hline & Middle-Inv & -0.0112 & 0.4944 & 0.822 & -0.1082 & 0.0859 \\
\hline & High-Inv & $-0.1704 *$ & 0.4944 & 0.001 & -0.2675 & -0.734 \\
\hline \multirow{3}{*}{$\begin{array}{l}\text { Middle } \\
\text { investment }\end{array}$} & Low-Inv & -0.0112 & 0.4944 & 0.822 & -0.0859 & 0.1082 \\
\hline & Middle-Inv & & & & & \\
\hline & High-Inv & $-0.1593^{*}$ & 0.4944 & 0.001 & -0.2564 & -0.622 \\
\hline \multirow{3}{*}{$\begin{array}{l}\text { High } \\
\text { investment }\end{array}$} & Low-Inv & $-0.1704 *$ & 0.4944 & 0.001 & -0.0734 & 0.2675 \\
\hline & Middle-Inv & $-0.1593^{*}$ & 0.4944 & 0.001 & -0.0622 & 0.2564 \\
\hline & High-Inv & & & & & \\
\hline
\end{tabular}

*the mean difference at 0.05 levels is meaningful.

According to the figure 1, the financial performance (ROA) of the companies which have higher investments, remarkably differ from the other groups. Hence, it can be concluded that the more the amount of investments in cooperative sector, the higher will be these companies` return on asset (ROA). According to the table, this performance difference is meaningful only between a group with higher investments and the other ones.

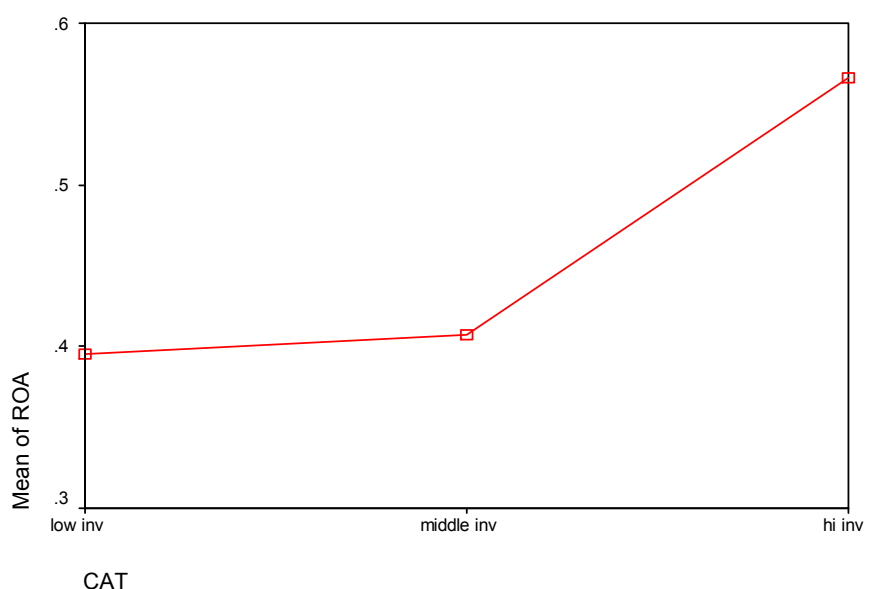

Figure 1- comparing ROA of investment quartiles 
Furthermore, the difference between the two groups with low and middle investments is not meaningful.

5. 6. Financial performance comparison among different parts of the cooperative sector in the group with low investment

At the next step, the financial performance of different sectors is examined and compared in each group (low, middle and high investment). First, descriptive Statistics of different sectors 'financial performances (within low investment group) are analyzed and compared.

Table 10- Descriptive statistics of ROA (various sectors at lower quartile of investment)

\begin{tabular}{|c|c|c|c|c|c|c|c|}
\hline \multirow[b]{2}{*}{ Description } & \multirow[b]{2}{*}{ Number } & \multirow[b]{2}{*}{ Mean } & \multirow{2}{*}{$\begin{array}{l}\text { Standard } \\
\text { deviation }\end{array}$} & \multicolumn{2}{|c|}{ 95\% Confidence interval } & \multirow[b]{2}{*}{ Minimum } & \multirow[b]{2}{*}{ Maximum } \\
\hline & & & & $\begin{array}{l}\text { Lower } \\
\text { bound }\end{array}$ & $\begin{array}{l}\text { Upper } \\
\text { bound }\end{array}$ & & \\
\hline Industry & 42 & 0.3080 & 0.48130 & 0.1580 & 0.4580 & -0.39 & 2.15 \\
\hline Agriculture & 45 & 0.4735 & 0.45538 & 0.3367 & 0.6103 & -0.0 & 1.73 \\
\hline Services & 85 & 0.3407 & 0.48672 & 0.2358 & 0.4457 & 0.01 & 2.62 \\
\hline Others & 68 & 0.4671 & 0.62654 & 0.3154 & 0.6187 & -0.87 & 2.47 \\
\hline Total & 240 & 0.3957 & 0.52558 & 0.3289 & 0.4625 & -0.87 & 2.62 \\
\hline
\end{tabular}

Table 11- ANOVA (Comparing the ROA of different sectors at low investment quartile)

\begin{tabular}{lllllll}
\hline Description & & Sum of squares & df & Mean squares & F & Sig. \\
\hline \multirow{3}{*}{ Model } & Between groups & 1.198 & 3 & 0.399 & 1.455 & 0.228 \\
& Within groups & 64.822 & 236 & 0.275 & & \\
& Total & 62.021 & 239 & & \\
\hline
\end{tabular}

Table 11 shows that there is no meaningful relationship between financial performances (ROA ratio) in different sectors of investment (low investment), which means that there is no meaningful relationship between financial performances (ROA ratio) of various industries in a group of the companies with higher investments as well.

5. 7. Financial performance comparison among different parts of the cooperative sector in the group with middle investment

Tables 12 and 13 present descriptive Statistics of different sectors` financial performances and their comparing results of the group with middle investments. 
Table 12-Descriptive statistics of ROA (various sectors at middle quartile of investment)

\begin{tabular}{|c|c|c|c|c|c|c|c|}
\hline \multirow[b]{2}{*}{ Description } & \multirow[b]{2}{*}{ Number } & \multirow[b]{2}{*}{ Mean } & \multirow[b]{2}{*}{$\begin{array}{l}\text { Standard } \\
\text { deviation }\end{array}$} & \multicolumn{2}{|c|}{ 95\% Confidence interval } & \multirow[b]{2}{*}{ Minimum } & \multirow[b]{2}{*}{ Maximum } \\
\hline & & & & $\begin{array}{l}\text { Lower } \\
\text { bound }\end{array}$ & $\begin{array}{l}\text { Upper } \\
\text { bound }\end{array}$ & & \\
\hline Industry & 24 & 0.4840 & 0.37101 & 0.3273 & 0.6406 & 0.00 & 1.17 \\
\hline Agriculture & 57 & 0.9216 & 0.88071 & 0.6879 & 1.1553 & -0.65 & 2.16 \\
\hline Services & 73 & 0.4460 & 0.53165 & 0.3219 & 0.5700 & 0.92 & 2.82 \\
\hline Others & 86 & 0.3425 & 0.52019 & 0.2309 & 0.4540 & -1.08 & 2.58 \\
\hline Total & 240 & 0.5256 & 0.65418 & 0.4425 & 0.6088 & -1.08 & 2.82 \\
\hline
\end{tabular}

Table 13-ANOVA (Comparing the ROA of different sectors at middle investment quartile)

\begin{tabular}{lllllll}
\hline Description & & Sum of squares & df & Mean squares & F & Sig. \\
\hline \multirow{3}{*}{ Model } & Between groups & 12.327 & 3 & 4.109 & 10.780 & 0.000 \\
& Within groups & 89.954 & 236 & 0.381 & & \\
& Total & 102.281 & 239 & & & \\
\hline
\end{tabular}

Since significance coefficient is lower than $5 \%$, it may be concluded that at least, there is a meaningful financial performance difference between two groups of the sectors. Thus, the multiple comparisons tests (table 14) should be examined precisely. According to the table 14 and the figure 2, there is a meaningful difference between the financial performances of the agricultural companies in comparison with the industrial and service and other ones. But the difference among other industries is not meaningful. This means that in a group with middle investments lead to higher investments in agricultural sector, which significantly differs in efficiency from investing in other sectors. 
Moradi \& Nematollahi /International Journal of Research in Business and Social Sciences

Vol 2, No 2, 2013. ISSN: 2147-4478

Table 14- multiple comparison of different sectors` ROA at middle investment quartiles

\begin{tabular}{|c|c|c|c|c|c|c|}
\hline \multirow{2}{*}{ Group (I) } & \multirow{2}{*}{ Group (J) } & \multirow{2}{*}{ mean difference $(\mathbf{i}-\mathbf{j})$} & \multirow{2}{*}{ Std. error } & \multirow{2}{*}{ Sig. } & \multicolumn{2}{|c|}{$\mathbf{9 5 \%}$ Confidence interval } \\
\hline & & & & & Lower bound & Upper bound \\
\hline \multirow{4}{*}{ Industry } & Industry & & & & & \\
\hline & Agriculture & $-0.4376^{*}$ & 0.15023 & 0.004 & -0.7336 & -0.1417 \\
\hline & services & 0.0380 & 0.14527 & 0.794 & -0.2482 & 0.3242 \\
\hline & Other & 0.1415 & 0.14253 & 0.322 & -0.1339 & 0.4223 \\
\hline \multirow{5}{*}{ Agriculture } & Industry & $0.4376^{*}$ & 0.15023 & 0.004 & 0.1417 & 0.7336 \\
\hline & Agriculture & & & & & \\
\hline & & & & & & \\
\hline & services & $-0.4756^{*}$ & 0.10913 & 0.000 & 0.2606 & 0.6609 \\
\hline & Other & $0.5971 *$ & 0.10545 & 0.000 & 0.3714 & 0.7869 \\
\hline \multirow{4}{*}{ Services } & Industry & -0.0380 & 0.14527 & 0.794 & -0.3242 & 0.2482 \\
\hline & Agriculture & $-0.4756^{*}$ & 0.10913 & 0.000 & -0.6906 & -0.2606 \\
\hline & services & & & & & \\
\hline & Other & 0.1035 & 0.9825 & 0.293 & -0.0901 & 0.2971 \\
\hline \multirow{4}{*}{ Others } & Industry & 0.1415 & 0.14253 & 0.322 & -0.4223 & 0.1393 \\
\hline & Agriculture & $0.5971 *$ & 0.10545 & 0.000 & -0.7869 & -0.3714 \\
\hline & services & -0.1035 & 0.9825 & 0.293 & -0.2971 & 0.0901 \\
\hline & Other & & & & & \\
\hline
\end{tabular}

*the mean difference at levels 0.05 is meaningful.

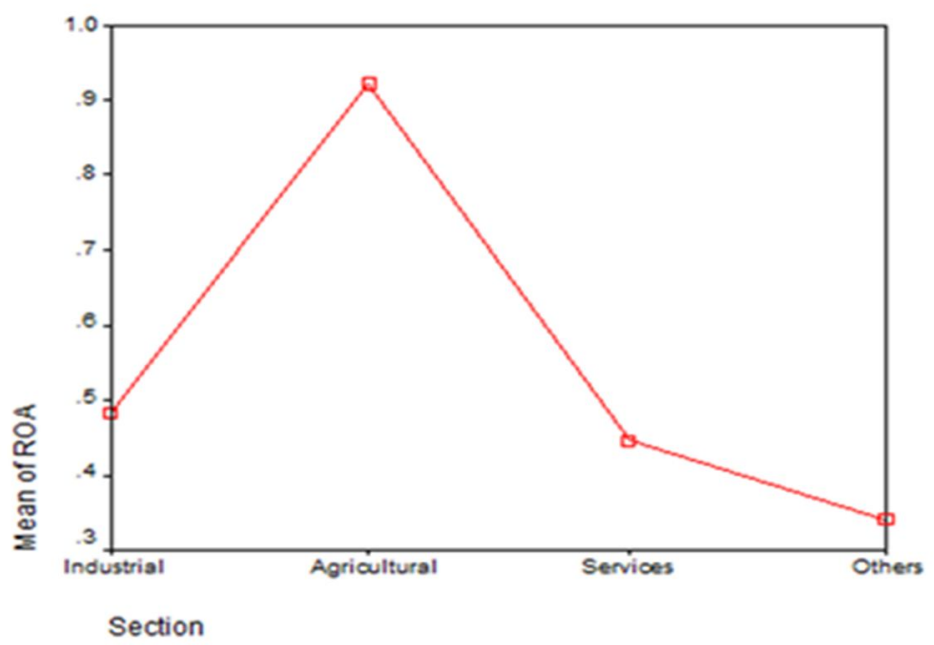

Figure 2- Comparing the ROA of different sectors at middle investment levels 
5. 8. Financial performance comparison among different parts of cooperative sector in the group with high investment

Tables 15 and 16 present descriptive Statistics of different sectors` financial performances and their comparing results of the group with high investments.

Table 15-Descriptive Statistics relating to the ROA (various sectors at high quartile of investments)

\begin{tabular}{|c|c|c|c|c|c|c|c|}
\hline \multirow{2}{*}{ Description } & \multirow{2}{*}{ Number } & \multirow{2}{*}{ Mean } & \multirow{2}{*}{$\begin{array}{l}\text { Std. } \\
\text { deviation }\end{array}$} & \multicolumn{2}{|c|}{$\begin{array}{l}95 \% \\
\text { interval }\end{array}$} & \multirow{2}{*}{ Minimum } & \multirow{2}{*}{ Maximum } \\
\hline & & & & $\begin{array}{l}\text { Lower } \\
\text { bound }\end{array}$ & $\begin{array}{l}\text { Upper } \\
\text { bound }\end{array}$ & & \\
\hline Industry & 36 & 0.15179 & 0.61941 & 0.3101 & 0.7293 & 0.000 & 2.06 \\
\hline Agriculture & 60 & 0.6194 & 0.60780 & 0.4624 & 0.7764 & 0.000 & 2.97 \\
\hline Services & 82 & 0.6100 & 0.58138 & 0.4823 & 0.7378 & 0.000 & 2.44 \\
\hline Other & 62 & 0.2622 & 0.38260 & 0.1650 & 0.3593 & -0.13 & 1.41 \\
\hline Total & 240 & 0.5090 & 0.56717 & 0.4368 & 0.5811 & -0.13 & 2.97 \\
\hline
\end{tabular}

Table 16-ANOVA (comparing the ROA of different sectors at high investment quartile)

\begin{tabular}{lllllll}
\hline Description & & Sum of squares & df & Mean squares & F & Sig. \\
\hline \multirow{3}{*}{ Model } & Between groups & 5.394 & 3 & 1.783 & 5.883 & 0.001 \\
& Within groups & 71.532 & 236 & 0.303 & & \\
& Total & 76.881 & 239 & & \\
\hline
\end{tabular}

Since significance level is lower than $5 \%$, it may be concluded that at least, there is a meaningful financial performance difference between two groups of industries. Table 17 and figure 3 present multiple comparison results. 
Table 17-Multiple comparison of different sectors` ROA at high investment quartiles

\begin{tabular}{|c|c|c|c|c|c|c|c|c|}
\hline \multirow[t]{2}{*}{ Group (I) } & & \multirow[t]{2}{*}{ Group (J) } & \multirow{2}{*}{\multicolumn{2}{|c|}{$\begin{array}{l}\text { Mean difference } \\
\text { (i-j) }\end{array}$}} & \multirow[t]{2}{*}{ Std. error } & \multirow[t]{2}{*}{ Sig. } & \multicolumn{2}{|c|}{$\begin{array}{l}95 \% \\
\text { Confidence } \\
\text { interval }\end{array}$} \\
\hline & & & & & & & $\begin{array}{l}\text { Lower } \\
\text { bound }\end{array}$ & $\begin{array}{l}\text { Upper } \\
\text { bound }\end{array}$ \\
\hline \multirow{4}{*}{ Industry } & & Industry & & & & & & \\
\hline & & Agriculture & -0.0997 & & 0.11607 & 0.391 & 0.3283 & 0.1290 \\
\hline & & services & -0.0903 & & 0.11007 & 0.413 & 0.3072 & 0.1265 \\
\hline & & Others & $0.2575^{*}$ & & 0.11536 & 0.027 & 0.0303 & 0.4848 \\
\hline \multirow{4}{*}{ Agriculture } & & Industry & 0.0997 & & 0.11607 & 0.391 & $\begin{array}{l}- \\
0.1290\end{array}$ & 0.3283 \\
\hline & & Agriculture & & & & & & \\
\hline & & services & 0.0093 & & 0.09353 & 0.920 & 0.1749 & 0.1936 \\
\hline & & Others & $0.3572 *$ & & 0.09970 & 0.000 & 0.1608 & 0.5536 \\
\hline \multirow{4}{*}{ Services } & & Industry & 0.0903 & & 0.11007 & 0.413 & $\overline{0}-1265$ & 0.3072 \\
\hline & & Agriculture & -0.0903 & & 0.09353 & 0.920 & $\begin{array}{l}- \\
0.1936\end{array}$ & 0.1749 \\
\hline & & services & & & & & & \\
\hline & & Others & $-0.3479 *$ & & 0.09266 & 0.000 & 0.1653 & 0.5304 \\
\hline \multirow{4}{*}{ Other } & Industry & $-0.2575^{*}$ & 0.11536 & 0.027 & -0.4848 & \multicolumn{2}{|c|}{-0.0303} & \\
\hline & Agriculture & $-0.3572^{*}$ & 0.09970 & 0.000 & -0.5536 & \multicolumn{2}{|c|}{-0.1608} & \\
\hline & services & $-0.3479 *$ & 0.09266 & 0.000 & -0.5304 & \multicolumn{2}{|c|}{-0.1653} & \\
\hline & Others & & & & & & & \\
\hline
\end{tabular}

*The mean difference at levels 0.05 is meaningful.

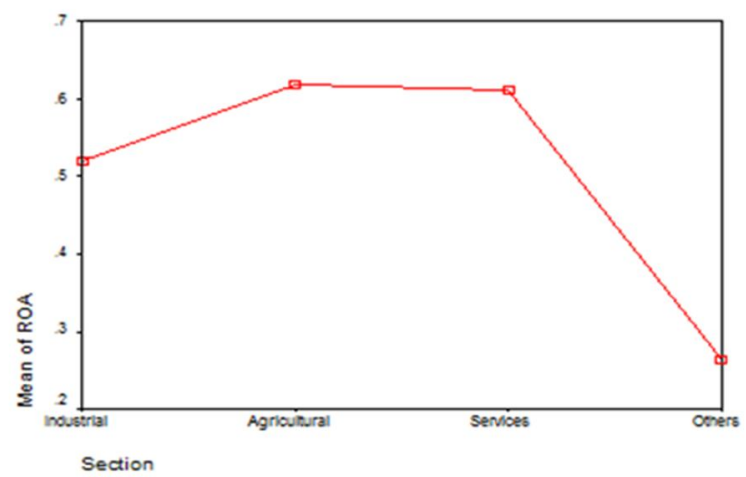

Figure 3- comparing the ROA of different sectors at high investment levels 
According to the figure 17 and the figure 3, there is a meaningful difference between the financial performances of different companies in comparison with industrial, services, and agricultural sectors. This means that investing in other groups like the one with high investment has led to lower profits while service, agricultural and industrial sectors of Fars have experienced high investments

\section{Conclusion}

In this paper, the relationship between the investment and employment of cooperative companies were examined. The results show that there is a meaningful relationship between investment and employment in these companies. Thus, this assumption is approved, which is similar to the research of Bazdar Ardebili and Rezaee Arjroudi (2008). According to the significance of investment in employment section, it can be concluded that the employment rates will grow in cooperative companies due to an increase in capital investment. The results of testing the second hypothesis show that there is a meaningful difference between the performances of the cooperative companies on the basis of their investments in different sectors. Finally, the second hypothesis of this paper is approved as well. The findings, are closely similar to Karimi et al. (2010), Noorvash and Yazdani (2010), Shourvarzi and Azadvar (2010), and Sung (2009). Aggregately, the companies with higher investment take advantages of higher returns on assets (ROA) in comparison with those with low or middle investments, and it can be concluded that increasing investments in some sectors such as agriculture and industry has resulted in higher efficiency. In accordance with the results it is suggested that increasing the rates of employment in industrial sectors will result in higher rates of employment in total and investing in agricultural and cooperative companies is economically more affordable. Creating job opportunities relating to the type of production and services will decrease unemployment rates, too. Investing in small sectors, growing it gradually and working assembly by performing activities cooperatively.

\section{References}

Bazdar-Ardebili, P. and Rezaei-Arjroudi, A. (2008) Determining the relationship between investment and employment in transportation sector. Transportation Research 5(4): 295-306.

Fathi, S. and Tavakkoli, Y. (2009) Evaluating the relationship between working capital management and the financial performance of economic enterprises. Commercial Evaluation 36: 104-116.

Ghayur, M. (2009) Practical guidelines to the performance evaluation of executive agencies. research, Scientific and Technical Journal 8: 60-74.

Haj-Sayyed-Javadi, M. and Samadi, M. (2009) Developing a multivariate statistical model to rank agro-industry companies on the basis of financial performance under the cover of the ministry of agriculture during the period 1384 to 1385. Agricultural Economics and Development (17 ${ }^{\text {th }}$ year) 18: 1-26.

Haji-Jabbari A.R. and Sarabadi, M. (2007) Practical guidelines to the performance evaluation of executive agencies. Iran 's training and industrial research center, first print.

Hoseini, SH. And Souri, A.R. (2009) total policies of the principle No. 44, strategy of applying modern financing methods of cooperatives in Iran, Cooperation 20(212): 1-32.

Jameiee, R. (2004) Methods of the financial performance evaluation of cooperative companies. Journal of Cooperation 153: 25-37.

Karimi, F., Akhlaghi, H.A. and Rezaei-Mehr, F. (2010) Investigating the effect of financial leverage and growth opportunity on investment decisions of firms accepted in TSE. Financial Accounting 2(8): 60-74.

Lahsaiee- zadeh, A.H. (1384) Sociology of agriculture. Tehran: Ettelaat press, $1^{\text {st }}$ edition.

Mollahosseini, A. and Mohammadi, M. (2010) Relationships between managers` ability and the performance of the consumption cooperative companies of Kerman. Cooperation $\left(21^{\text {st }}\right.$ year) $1: 125-141$.

Noravesh, I. and Yazdani, S (2010) Investigating the effect of financial leverage on investments. Financial Accounting Research Journal 2(2): 35-48. 
Ourangi, M, Hosseini-Nya, G.H. and Heidari, A.G. (2010) Measuring effective structures on the tendency of graduates and senior students of agriculture to employment in cooperation sector in southern Khorasan province. Cooperation (21 $1^{\text {st }}$ year) 1: 101-112.

Shourvarzi, M.R. and Azadvar, I. (2010) Analysis of the relationship between investment opportunities and firms performance. Management Accounting Journal 3(6): 13-23.

Sung, C.B. (2009) on the interactions of financing and investment decisions. Managerial Finance 35(8): 691-699.

Tajalli, A., Aziz-Nejad, S. and Mir-Shamsi, A. (2010) Effects of interest rates reduction on inflation, employment and investment. Tehran: IRI Parliament Research Center.

Zimmerer W.T. and Scarboroagh, N. (1996) Entrepreneurship and the New Venture Formation, Prentice Hall, International Edition. 